\begin{tabular}{|l|l|l|}
\hline \multicolumn{2}{|c|}{ PublisherInfo } \\
\hline \hline PublisherName & $:$ & BioMed Central \\
\hline \hline PublisherLocation & $:$ & London \\
\hline \hline PublisherImprintName & $:$ & BioMed Central \\
\hline \hline
\end{tabular}

\title{
Rat genetic marker database
}

\begin{tabular}{|l|l|l||}
\hline \multicolumn{2}{|c|}{ ArticleInfo } \\
\hline \hline ArticleID & $:$ & 25 \\
\hline \hline ArticleDOI & $:$ & $10.1186 /$ ar-2000-2-webreport0009 \\
\hline \hline ArticleCitationID & $:$ & 0009 \\
\hline \hline ArticleSequenceNumber & $:$ & 21 \\
\hline \hline ArticleCategory & $:$ & Web Report \\
\hline ArticleFirstPage & $:$ & 1 \\
\hline \hline ArticleLastPage & $:$ & 3 \\
\hline \hline & & RegistrationDate : 2000-4-18 \\
\hline ArticleHistory & $:$ & OnlineDate \\
\hline \hline ArticleCopyright & $:$ & Current Science Ltd2000-4-18 \\
\hline \hline ArticleGrants & $:$ & \\
\hline \hline ArticleContext & $:$ & 130752211 \\
\hline \hline
\end{tabular}




\section{Overview}

This site is hosted by the US National Institute of Arthritis and Musculoskeletal and Skin Diseases (NIAMS), which is one of the National Institutes of Health. The rat genetic project is managed by $\mathrm{Dr}$ Ronald Wilder, head of the Arthritis and Rheumatism Branch (ARB) of the Institute. The ARB is undertaking a major project to explore the regulation of susceptibility and resistance in inbred rat strains by genetic linkage mapping and related experimental approaches. The purpose of the site is to make available the data compiled by the group.

\section{Content}

This site has little content and is primarily a medium for the rat genetic database. However, there are sections outlining the aims, scope and organisation of the database, the methods and protocols used, and the people and publications (with links to online journals) associated with the project.

The site hosts a database of genetic markers that have been developed and mapped by the ARB in the context of mapping loci that regulate experimental arthritis and related phenotypes. The database also has information on additional genetic markers that were developed by other groups but have also been mapped by the ARB in experimental crosses. The ARB rat database of genetic markers is divided into two groups of tables, each organised by chromosome.

The first group of tables, the PCR Primer Database, lists marker loci alphabetically. Experimental crosses in which these markers have been mapped, or those that can potentially be mapped, are indicated here. The second set of tables, the Rat Genetic Maps, describes the relative locations of various genetic marker loci in the form of both integrated and single cross genetic linkage maps. These maps are provisional and subject to change as error checking and additional mapping is conducted.

Additional information on each marker - eg, alternative locus names, associated genes, primer sequences - is available through links in the tables. A datafile containing genotypes for constructing the various maps is also available on the site.

\section{Other comments}


This text-only site has only five sections so navigation is simple, using either browser buttons or text links on each page. Most sections were last updated in July 1999.

\section{Evaluation}

The Rat Genetic Linkage project is of value to all scientists working to elucidate the genetic basis of arthritis and other autoimmune diseases.

\section{References}

1. ARB Rat Genetic Database. [http://www.nih.gov/niams/scientific/ratgbase/index.htm] 